\title{
Commentary: How (and why) to make it mini
}

\author{
J. James Edelman, MBBS(Hons), PhD, and Vinod H. Thourani, MD
}

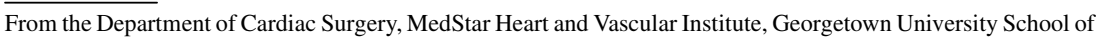
Medicine, Washington, DC.

Disclosures: Authors have nothing to disclose with regard to commercial support.

Received for publication Oct 19, 2018; accepted for publication Oct 20, 2018; available ahead of print Nov 16, 2018.

Address for reprints: Vinod H. Thourani, MD, Department of Cardiac Surgery, MedStar Heart and Vascular Insti-

tute, 110 Irving St, Ste 6D15G, Washington, DC 20010 (E-mail: vinod.h.thourani@medstar.net).

J Thorac Cardiovasc Surg 2019;157:1968-9

$0022-5223 / \$ 36.00$

Copyright (C) 2018 by The American Association for Thoracic Surgery

https://doi.org/10.1016/j.jtcvs.2018.10.083

The management of structural heart disease, specifically for the treatment of aortic stenosis and mitral regurgitation, has radically changed over the past decade. Before the development of transcatheter valve techniques, more than $80 \%$ of all surgeries were performed via a traditional median sternotomy. In the current climate of less-invasive options and Internet accessibility, patients are increasingly searching for minimally invasive therapy options for their valve disease. However, minimally invasive surgical techniques are used in a minority of cases performed in the United States. In a recent analysis of the Society of Thoracic Surgeons database from 2011 to $2016,{ }^{1}$ isolated minimally invasive mitral valve surgery was performed in only $23 \%$ of patients (32.4\% in patients with degenerative prolapse); a small increase from the $20 \%$ reported in $2008 .{ }^{2}$ Unlike mitral valve surgery performed via a conventional sternotomy, minimally invasive mitral or aortic surgery involves a deviation from normal operating room environments that affect not only the surgeon and assistant, but also the entire operating team, including members representing anesthesia, nursing, and perfusion. We see this as the major barrier to its uptake.

The primary goal of mitral valve surgery for degenerative disease should be a durable repair. It must be remembered that the gold standards of mitral valve repair set by Carpentier $^{3}$ and David and colleagues ${ }^{4}$ were performed primarily through a sternotomy. However, because several lessinvasive transcatheter technologies using transapical and transseptal access are currently in early feasibility or pivotal trials in the United States, surgeons will need to improve the appeal of the treatment we offer. Minimally invasive mitral surgery provides a level of invasiveness more acceptable to patients and a durable repair using contemporary valve repair techniques.

The evidence for minimally invasive mitral valve surgery is limited to single institution data. Large series and propensity-matched cohorts confirm safety and suggest satisfactory longer-term durability compared with sternotomy and there appears to be only a modest difference in

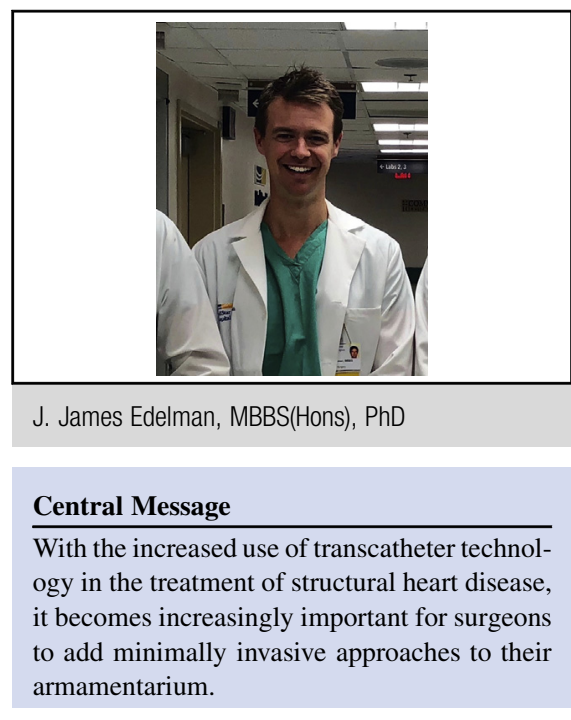

See Article page 1958.

the length of stay. ${ }^{5-8}$ Further, pain scores are reduced and there may be a faster return to normal activities. 9,10

Nissen and colleagues ${ }^{11}$ elegantly describe the establishment of a minimally invasive valve surgery program. Whilst the authors do not report clinical outcomes, we suspect that increasing annual procedure volume must reflect their program's success. We agree with their key points on establishment of a consistent, high-quality team, good patient selection (both the clinical and anatomic characteristics as assessed with computed tomography of the chest and pelvis as standard of care), and training with subsequent mentorship. We agree with the authors that the most important aspect of a minimally invasive valve program should remain clinical outcomes and an unwavering pursuit of excellence.

With the development of a structural valve heart team at most institutions, we foresee that practice patterns in the future will change from referral to a single cardiologist or surgeon to direction to a center with a multidisciplinary valve team. This team should have shared leadership amongst surgeons and cardiologists (interventional, imaging, and noninterventional) and with active involvement of anesthesia and nursing staff. Such a team is best placed to select the ideal treatment for each patient within the experience of each hospital network. We believe that this team should be able to provide a patient with all 3 options for care of valve disease: traditional median sternotomy, minimially invasive, and transcatheter technologies. 
The treatment of valvular heart disease is advancing rapidly using transcatheter techniques. If surgeons want to stay in the race for the management of heart disease in these patients, they must advance their skills to provide durable outcomes using minimally invasive surgical valve techniques.

\section{References}

1. Gammie JS, Chikwe J, Badhwar V, Thibault DP, Vemulapalli S, Thourani VH, et al. Isolated mitral valve surgery: the Society of Thoracic Surgeons Adult Cardiac Surgery Database analysis. Ann Thorac Surg. 2018;106:716-27.

2. Gammie JS, Zhao Y, Peterson ED, O’Brien SM, Rankin JS, Griffith BP. Lessinvasive mitral valve operations: trends and outcomes from the Society of Thoracic Surgeons Adult Cardiac Surgery Database. Ann Thorac Surg. 2010; 90:1401-8.

3. Braunberger E, Deloche A, Berrebi A, Abdallah F, Celestin JA, Meimoun P, et al. Very long-term results (more than 20 years) of valve repair with carpentier's techniques in nonrheumatic mitral valve insufficiency. Circulation. 2001;104(12 Suppl 1):I8-11.

4. David TE, Armstrong S, Ivanov J. Chordal replacement with polytetrafluoroethylene sutures for mitral valve repair: a 25-year experience. J Thorac Cardiovasc Surg. 2013;145:1563-9.
5. Sündermann SH, Sromicki J, Rodriguez Cetina Biefer H, Seifert B, Holubec T, Falk V, et al. Mitral valve surgery: right lateral minithoracotomy or sternotomy? A systematic review and meta-analysis. J Thorac Cardiovasc Surg. 2014;148: 1989-95.e4.

6. Hawkins RB, Mehaffey JH, Mullen MG, Nifong WL, Chitwood WR, Katz MR, et al. A propensity matched analysis of robotic, minimally invasive, and conventional mitral valve surgery. Heart. June 18, 2018 [Epub ahead of print].

7. Miceli A, Murzi M, Canarutto D, Gilmanov D, Ferrarini M, Farneti PA, et al. Minimally invasive mitral valve repair through right minithoracotomy in the setting of degenerative mitral regurgitation: early outcomes and long-term follow-up. Ann Cardiothorac Surg. 2015;4:422-7.

8. Goldstone AB, Cohen JE, Howard JL, Edwards BB, Acker AL, Hiesinger W, et al. A "repair-all" strategy for degenerative mitral valve disease safely minimizes unnecessary replacement. Ann Thorac Surg. 2015;99:1983-91.

9. Svensson LG, Atik FA, Cosgrove DM, Blackstone EH, Rajeswaran J, Krishnaswamy G, et al. Minimally invasive versus conventional mitral valve surgery: a propensity-matched comparison. J Thorac Cardiovasc Surg. 2010;139: 926-32.e2.

10. Speziale G, Nasso G, Esposito G, Conte M, Greco E, Fattouch K, et al. Results of mitral valve repair for Barlow disease (bileaflet prolapse) via right minithoracotomy versus conventional median sternotomy: a randomized trial. J Thorac Cardiovasc Surg. 2011;142:77-83.

11. Nissen AP, Nguyen S, Abreu J, Nguyen TC. The first 5 years: building a minimally invasive valve program. J Thorac Cardiovasc Surg. 2019;157:1958-65. 